\title{
Effects of Varieties, Nitrogen Fertilization and Seeding Rate on Growth, Seed and Oil Yield of Linseed
}

\author{
Sakatu Hunduma* Legesse Admassu Abdissa Mekonnen Birhanu Mengistu \\ Ethiopian Institute of Agricultural Research, P.O.Box, 2003, Addis Ababa, Ethiopia
}

\begin{abstract}
The experiment was carried out for three years from 2016 to 2018 at Wolmera to study the response of different seeding rates and nitrogen fertilizer of linseed varieties. The experiment was arranged in RCBD factorial combination with three replications. Two improved varieties (kassa- 2 and Tolle), three seeding rates (20, 30 and $40 \mathrm{~kg} / \mathrm{ha})$ and four Nitrogen rates $(0,23,46$ and $69 \mathrm{~kg} \mathrm{~N} / \mathrm{ha})$ were used. Data was collected and subjected to analysis of variance using SAS/STAT (Windows 9) (SAS Institute, 2004) software. Mean separation was done using list significant difference (LSD test). The analysis of variance revealed non-significant difference for grain yield between the two varieties $(p<0.05)$. Seed rate was Significant to affect grain yield but other parameters tasted were not significantly affected by seed rate. Nitrogen rate had a significant effect on all parameters tasted ( $<<0.05$ except seed oil content. Higher seed yield $(1734.9 \mathrm{~kg} / \mathrm{ha})$ was obtained by the application of $69 \mathrm{~kg} N / \mathrm{ha}$ but it was not statistically different from the yield obtained by $46 \mathrm{~kg} \mathrm{~N} / \mathrm{ha}(1722.5 \mathrm{~kg} / \mathrm{ha})$. Interaction effect was not significant enough to alter seed and biomass yield. Partial economic analysis revealed that seed rate of 30 $\mathrm{kg} / \mathrm{ha}$ and $46 \mathrm{~kg} / \mathrm{ha}$ nitrogen fertilizer rate were the optimum rates for linseed production at the study area.
\end{abstract}

Keywords: linseed, nitosol, nitrogen rate, seed rate, yield

DOI: $10.7176 / J N S R / 12-15-04$

Publication date:August $31^{\text {st }} 2021$

\section{INTRODUCTION}

Linseed (Linum usitatissimum) is one of the most versatile and useful crops that has been grown for thousands of years (Gensel and Morris, 2003). Linseed is a rich source of both non-edible and edible oil. Edible linseed oil is used for human consumption and contains a linolenic acid, a polyunsaturated fatty acid exceeding all major plant oils and even fish oil (Hunter 1990) that has nutritional and health benefits (Bickert et al., 1994, Heller et $a l ., 2010)$. Beside from linolenic acid, linseed is becoming increasingly popular as a nutritional and functional food due to its high content of therapeutic health promoting substances such as $\omega-3$ fatty acid, valuable protein, dietary fiber, lecithin, and lignans-chemical compounds of major importance for human health (Bhatty and Cherdkiatgumchai, 1990; Ganorkar and Jain, 2013). Oils with high linolenic acid content dry rapidly, which is a trait important to the paint industry (Green \& Marshall, 1981).

Among oilseeds, linseed (Linum usitatissimum) stands third next to sesame and noug respectively in areas coverage and total production (CSA, 2017). Among the factors which determine quality, a major role is played by the nutrient supplies, especially $\mathrm{N}$ fertilization. Deficient $\mathrm{N}$ supplies have a negative effect, particularly on the yield components, and may lead to a lower oil yield, while less effect is exerted on the oil content (Zoltán \& IldikóIványi, 2005). Excessive $\mathrm{N}$ supplies lead to a substantial decline in both oil content and oil yield, especially above 80-120 kg ha1 N (Hocking \& Pinkerton, 1991; 1993). On the other hand, manipulation of crop seeding rate and row spacing can maximize yield (Gubbles and Kenaschuk, 1989; Lafond, 1993). Despite its importance there is limited information available on linseed to develop an efficient agronomic guideline that can guarantee high and good quality seed yield in Ethiopia, especially on the recently released varieties. In particular, information is not available on the response of linseed to management strategies like nitrogen fertilization and the manipulation of the seeding rate to optimize yield. Under intensive conditions, linseed seed yield ranges up to $30 \mathrm{qt} / \mathrm{ha}$, compared to a world average of $10 \mathrm{qt} / \mathrm{ha}$, similar to average yields in Ethiopia. Improvements in linseed cultivation technology are a significant element in meeting the growing domestic requirements for quality linseed oil production for food and industrial purposes. So, the objective of this research were to evaluate the effect of different levels of seeding rates and nitrogen fertilization on growth, seed and oil yield of linseed varieties under Nitosols soil condition.

\section{MATERIALS AND METHOD}

The experiment was conducted for three years (2016- 2018 in main cropping seasons) around Holetta areas, Wolmera district in the central highlands of Ethiopia. Holeta is located between $09^{\circ} 03^{\prime} \mathrm{N}$ latitude and $38^{\circ} 30^{\prime}$ E longitude, $30 \mathrm{~km}$ west of Addis Ababa, at an altitude of about $2400 \mathrm{~m}$ above sea level. The long- term average annual rainfall is $1144 \mathrm{~mm}$, about $85 \%$ of which is received from June to September with the remainder from January to May. The average minimum and maximum air temperatures are $6.2^{\circ} \mathrm{C}$ and $22.1^{\circ} \mathrm{C}$ respectively. The environment is seasonally humid and the major soil type of the trial sites is Eutric Nitisol (IUSS, 2015).

The experiment was designed in a randomized complete block design with three replication. The treatments 
were a factorial combination of two varieties early maturing (Kassa 2) and late maturing (Tolle) varieties, three seeding rates $(20,30$ and $40 \mathrm{~kg}$ ha-1) and four Nitrogen rates $(0,23,46$ and $69 \mathrm{~kg} \mathrm{~N}$ ha-1). In all plots, Phosphorus as triple superphosphate (TSP) was band applied at planting at the rate of $20 \mathrm{~kg} \mathrm{P} / \mathrm{ha}$. Urea was used as the source of $\mathrm{N}$, which was applied in a band half at planting and the remainder side dressed at tillering stage of the crop. A gross plot size of $2 \mathrm{~m}$ width and $3 \mathrm{~m}$ long was used. The seedbed was plowed three times before planting. Seed was drilled using $20 \mathrm{~cm}$ spacing between rows. Other cultural and management practices were carried out as per the recommendations.

\section{Data collection and Analysis}

Composite soil sample was collected before planting for analysis of $\mathrm{pH}, \mathrm{OM}$, total $\mathrm{N}$ and available $\mathrm{P}$ in each year. Linseed yield and yield related data collected includes plant height, number of capsules/plant, seed yield, biomass yield and seed oil content. Finally, data was subjected to analysis of variance using SAS/STAT (Windows 9) (SAS Institute, 2004) software. Mean separation was done using list significant difference (LSD test). Finally, simple partial budget analysis were carried out.

\section{RESULTS AND DISCUSION}

Some of the soil characteristics of the three trial fields used for the experiment each year was presented below (Table 1). According to the mean result values, the experimental area was slightly acidic ( $\mathrm{pH}=4.86)$, low in total nitrogen content $(0.134 \%)$ and medium in available $\mathrm{p}(6.93 \mathrm{ppm})$ and organic matter content $(1.64 \%)$.

Table 1: Soil characteristics of the study areas (three year)

\begin{tabular}{lllll}
\hline Parameters & Year 1 & Year 2 & Year 3 & Mean \\
\hline Soil pH(1:2.5 H2O) & 4.9 & 4.7 & 5.0 & 4.86 \\
Total N (\%) & 0.13 & 0.16 & 0.12 & 0.134 \\
Available P (ppm) & 5.2 & 8.4 & 7.2 & 6.93 \\
Organic matter (\%) & 1.82 & 1.5 & 1.62 & 1.64 \\
\hline
\end{tabular}

The analysis of the three year data indicated that the two varieties were not significantly different in all yield and yield related parameters tasted except seed oil content. Variety kassa 2 recorded significantly higher seed oil content than variety Tolle (Table 2 ).

The main effect of seed rate did not significantly affect any of the parameters tasted except seed yield. Similar to these findings Njuguna et al. (2008) reported that seed rates had no significant effects on plant height, spikes/m2 and 1000-seed weight. According to this research, as seed rate increases seed yield also show an increment. Seed yield obtained by the lowest seed rate $(20 \mathrm{~kg} / \mathrm{ha})$ was significantly different from the seed yield obtained from the seed rate of $30 \mathrm{~kg} / \mathrm{ha}$ but the seed yield difference due to $30 \mathrm{~kg} / \mathrm{ha}$ and $40 \mathrm{~kg} / \mathrm{ha}$ seed rates were statistically not significant (Table 2).

Nitrogen rate was significantly affected all parameters tasted except seed oil content (Table 2) similar to the findings of Zoltán \& IldikóIványi, 2005. As nitrogen level increases the seed yield increment was recorded in which the higher seed yield was obtained by the application of $69 \mathrm{~kg} \mathrm{~N} /$ ha but it is not statistically different than the yield obtained by $46 \mathrm{~kg} \mathrm{~N} /$ ha (Table 2) in this research. Similar findings have been reported by other researchers where application of nitrogen caused increased production of capsules (Dybing, 1964; Gad and ElFarouk, 1978; Hocking,1995). This increase in number of capsules per plant due to increase in nitrogen might be attributed to increase in vegetative growth which resulted in more number of capsules being carried by each plant. Plant height increases with increase in nitrogen level for both linseed varieties. This finding is in line with the findings of Ali et al., (2011). Additionally, linseed biomass yield also increase with increase in nitrogen level as indicated on the (Table 2). Colnenne et al., 1998 also reported an increase in biomass yield with increase in nitrogen level. Interaction effect of seed rate and nitrogen rate was not significantly affect any of the parameters tasted.

Partial budget analysis revealed that seed rate of $30 \mathrm{~kg} / \mathrm{ha}$ and $46 \mathrm{~kg}$ /ha nitrogen fertilizer rate was the optimum rates due to the fact that it gave the highest net benefit (Table 3). Linseed grain yield response to different nitrogen level indicated that there is an increase in grain yield with increase in nitrogen level and the highest grain yield was attained at the highest nitrogen level $(69 \mathrm{kgN} / \mathrm{ha})$ but the net benefit result indicated that even if the highest grain yield is recorded at this high nitrogen level $46 \mathrm{kgN} / \mathrm{ha}$ is economically profitable with maximum net benefit (49837.9Birr/ha) than $69 \mathrm{kgN} / \mathrm{ha}$ as indicated in detail on (Table 3). 
Table 2: The Main effects of varieties, seed rate and $\mathrm{N}$ rates on linseed yield \& yield related parameters \& seed oil content

\begin{tabular}{|c|c|c|c|c|c|}
\hline Treatment & $\begin{array}{l}\text { Mean } \\
\mathrm{PH}(\mathrm{cm})\end{array}$ & $\begin{array}{l}\text { Mean No. } \\
\text { capsules/plant }\end{array}$ & $\begin{array}{l}\text { Mean Biomass } \\
\text { yield }(\mathrm{kg} / \mathrm{ha})\end{array}$ & $\begin{array}{l}\text { Mean Seed } \\
\text { Yield }(\mathrm{kg} / \mathrm{ha})\end{array}$ & $\begin{array}{l}\text { Mean Seed Oil } \\
\text { content }(\%)\end{array}$ \\
\hline \multicolumn{6}{|l|}{ Varieties } \\
\hline Kassa 2 & $82.986 a$ & $23.7 \mathrm{a}$ & 2996.3a & $1177.82 \mathrm{a}$ & $41.62 \mathrm{a}$ \\
\hline Tolle & $83.014 a$ & $23.48 \mathrm{a}$ & $3097 \mathrm{a}$ & $1194.61 \mathrm{a}$ & $41.13 b$ \\
\hline \multicolumn{6}{|l|}{$\begin{array}{l}\text { Seed rate } \\
(\mathrm{Kg} / \mathrm{ha})\end{array}$} \\
\hline 20 & $82.396 \mathrm{a}$ & $24.6 \mathrm{a}$ & $2919.2 \mathrm{a}$ & $1133.5 b$ & $41.43 \mathrm{a}$ \\
\hline 30 & $82.583 a$ & $23.4 \mathrm{a}$ & $3076.8 \mathrm{a}$ & $1195.5 \mathrm{a}$ & 41.39a \\
\hline 40 & $84 a$ & $22.8 \mathrm{a}$ & $3144.7 \mathrm{a}$ & $1229.6 \mathrm{a}$ & $41.3 \mathrm{a}$ \\
\hline \multicolumn{6}{|c|}{$\begin{array}{l}\text { Nitrogen } \\
\text { rate }(\mathrm{kg} \mathrm{N} / \mathrm{ha})\end{array}$} \\
\hline 0 & $73.972 \mathrm{c}$ & $16.02 \mathrm{c}$ & $2272.9 c$ & $427 \mathrm{c}$ & $41.519 \mathrm{a}$ \\
\hline 23 & $82 b$ & $23.63 b$ & $3011.7 \mathrm{~b}$ & $860 \mathrm{~b}$ & $41.427 \mathrm{ab}$ \\
\hline 46 & $87 a$ & $26.35 \mathrm{a}$ & $3317.2 \mathrm{ab}$ & $1722.5 \mathrm{a}$ & $41.333 \mathrm{ab}$ \\
\hline 69 & $89 a$ & $28.48 \mathrm{a}$ & $3585.7 \mathrm{a}$ & $1734.9 \mathrm{a}$ & $41.22 b$ \\
\hline $\mathrm{CV}(\%)$ & 5.26 & 15.26 & 16.26 & 8.53 & 1.005 \\
\hline
\end{tabular}

Where, Means followed by the same letter within a table are not significantly different at $5 \%$ level of significance

Table 3 : Partial Budget analysis for seeding rate and nitrogen application

\begin{tabular}{llllllll}
\hline $\begin{array}{l}\text { Treatment } \\
\text { No. }\end{array}$ & $\begin{array}{l}\text { Seed Rate } \\
(\mathrm{kg} / \mathrm{ha})\end{array}$ & $\begin{array}{l}\text { Nitrogen } \\
\text { Rate } \\
(\mathrm{kg} \mathrm{N} / \mathrm{ha})\end{array}$ & $\begin{array}{l}\text { Average } \\
\text { Seed yield } \\
(\mathrm{kg} / \mathrm{ha})\end{array}$ & $\begin{array}{l}\text { Adjusted } \\
\text { Yield } \\
(\mathrm{kg} / \mathrm{ha})\end{array}$ & $\begin{array}{l}\text { Gross } \\
\text { income } \\
(\text { Birr/ha) }\end{array}$ & $\begin{array}{l}\text { Total variable } \\
\text { cost } \\
\text { (Birr/ha) }\end{array}$ & $\begin{array}{l}\text { Net } \\
\text { benefit } \\
(\mathrm{Birr} / \mathrm{ha})\end{array}$ \\
\hline 1 & 20 & 0 & 388.6 & 349.74 & 11541.4 & 800 & 10741.4 \\
2 & 20 & 23 & 807.8 & 727.02 & 23991.7 & 1396.5 & 22595.2 \\
3 & 20 & 46 & 1704.3 & 1533.87 & 50617.7 & 1993 & 48624.7 \\
4 & 20 & 69 & 1718.4 & 1546.56 & 51036.5 & 2589.5 & 48447 \\
5 & 30 & 0 & 426.5 & 383.85 & 12667.1 & 1200 & 11467.1 \\
6 & 30 & 23 & 820.2 & 738.18 & 24359.9 & 1796.5 & 22563.4 \\
7 & 30 & 46 & 1806.6 & 1625.94 & 53656 & 2393 & 51263 \\
8 & 30 & 69 & 1778.7 & 1600.83 & 52827.4 & 2989.5 & 49837.9 \\
9 & 40 & 0 & 435 & 391.5 & 12919.5 & 1600 & 11319.5 \\
10 & 40 & 23 & 925.8 & 833.22 & 27496.3 & 2196.5 & 25299.8 \\
11 & 40 & 46 & 1720.3 & 1548.27 & 51092.9 & 2793 & 48299.9 \\
12 & 40 & 69 & 1802.5 & 1622.25 & 53534.3 & 3389.5 & 50144.8 \\
\hline
\end{tabular}

Where, price of linseed grain per $100 \mathrm{~kg}=3300$ birr and price of linseed seed per $100 \mathrm{~kg}=4000 \mathrm{birr}$; and the price of $100 \mathrm{~kg}$ Urea=1193Birr was considered.

\section{CONCLUSION}

This research trial was carried out for three successive years to investigate best seed and nitrogen rate for linseed production at the study area in which two linseed varieties (Tolle and kassa 2) were used as a taste crop. The statistical data of three year indicated that: there was no significant grain yield difference observed between the two varieties but relatively high yield was recorded from the late maturing variety 'Tolle'. The varieties were significantly different only in seed oil content in which high seed oil content is recorded from kassa 2 variety. Significant grain yield difference was observed due to seed rates but other parameters tasted were not significantly affected due to the main effect of seed rates. Nitrogen rate had a significant effect on all parameters tasted except seed oil content. Linseed grain yield response to different nitrogen level indicated that there is an increase in grain yield with increase in nitrogen level and the highest grain yield was attained at the highest nitrogen level $(69 \mathrm{kgN} / \mathrm{ha})$ but the net benefit result indicated that $46 \mathrm{kgN} / \mathrm{ha}$ is economically profitable with maximum net benefit (49837.9Birr/ha) than $69 \mathrm{kgN} / \mathrm{ha}$. So, based on partial budget analysis and above results $30 \mathrm{~kg} / \mathrm{ha}$ seed rate and $46 \mathrm{kgN} / \mathrm{ha}$ were profitable for linseed production at the study area. Besides, it is recommended that this experiment would be further confirmed in other areas and soil types for linseed production in general. 


\section{ACKNOWLDGEMENT}

The author is grateful for the financial support provided by the Crop process of Holetta Agricultural Research Center (HARC) to undertake the experiment. My special gratitude also goes to agronomy research colleagues at HARC for their technical and material support throughout the entire work.

\section{REFERENCES}

Ali, S., Cheema, M.A., Wahid, M.A., Sattar, A. and M.F. Saleem. 2011. Comparative production potential of linola and linseed under different nitrogen levels. Crop and Environment 2: 33-36.

Bhatty, R.S., P. Cherdkiatgumchai. 1990. Compositional analysis of laboratory-prepared and commercial samples of linseed meal and of hull isolated from flax. Journal of the American Oil Chemists' Society, 67: 79-84.

Bickert C., Lühs W.W. Friedt . 1994. Variation for fatty acid content and triacylglycerol composition in different Linum species. Industrial Crops and Products, 2: 229-237.

Colnenne, C., J. M. Meynard, R. Reau, E. Justes, and Merrien A. 1998. Determination of a critical nitrogen dilution curve for winter oilseed rape. Annals of Botany 81:311-317.

CSA (Central statistical agency) agricultural sample survey. 2017. Report on area and production of major crops (private peasant holdings, Meher season). Volume I, Statistical bulletin, Addis Ababa, Ethiopia

Dybing C.D. 1964. Influence of nitrogen level on flax growth and oil production in varied environments. Crop Science 4: 491-494.

Gad, A.Y. and El-Farouk M. 1978. Influence of seeding rates and nitrogen levels on yield and some technological characters of flax. Journal of Agricultural Research 56:79-91.

Ganorkar P.M., R.K. Jain. 2013. Flaxseed - A nutritional punch. International Food Research Journal: 20: 519525.Genser, A. D. and N. D. Morris. 2003. History of cultivation and uses of flaxseed. In A. D. Muir and N.D. Westcott (eds). Flax - The genus £inum. Taylor and Francis. London.

Green, A.G.and D.R. Marshall. 1981. Variation for oil quantity and quality in Linseed (Linum usitatissimum). Australian Journal of Agricultural Research 32: 599-607.

Gubbels, G.H. and E.O. Kenaschuk. 1989. Effects of seeding rate on plant and seed charactertics of new flax cultivars. Canadian Journal of Plant Science 69: 791-795.

Heller K., Andruszewska A., Wielgusz K. (2010): The cultivation of linseed by ecological methods. Journal of Research and Applications in Agricultural Engineering, 3: 112-116.

Hocking P.J. 1995. Effects of nitrogen supply on the growth, yield components, and distribution of nitrogen in Linola. Journal of Plant Nutrition 18 (2): 257- 275.

Hocking, P. J. \& A. Pinkerton. 1993. Phosphorus nutrition of linseed (Linum usitatissimum L.) as affected by nitrogen supply: Effect on vegetative development and yield components. Field Crops Research 32: 101114.

Hunter J.E. (1990): N-3 fatty acids from vegetable oils. American Journal of Clinical Nutrition, 5: 809-814.

IUSS Working Group WRB. 2015. World reference base for soil resources. A frame work for international classification, correlation and communication (World soil report resources No.103).Rome: FAO; 2006.

Lafond, G.P. 1993. The effects of nitrogen, row spacing and seeding rate on on the yield of flax under zero tillage production system. Canadian Journal of Plant Science 73: 375-382.

Njuguna, M.N., Munene M., Mwangi, H.G., Akuja, A.K. (2008). Effect of seeding rates and nitrogen fertilizer on wheat grain yield on marginal areas of eastern Kenya. Kenya Agricultural Research Institute -Njoro NPBRC. P.O. Njoro, Kenya.

SAS Institute (2004). SAS/STAT guide for personnel computers, version 9, edition. Cary, NC: SAS Institute Inc.

Zoltán Izsáki \& IldikóIványi. 2005. Effect of Nutrient Supply on the Quality of Linseed and Hempseed. Journal of Natural Fibers. 1:4, 59-75. 